\title{
GENERALIZED VECTOR QUASI-VARIATIONAL-LIKE INEQUALITIES
}

\author{
JIAN-WEN PENG
}

Abstract. In this paper, some existence theorems for the generalized vector quasi-variational-like inequalities without monotonicity are obtained.

Mathematics subject classification (2000): 49J40, 47H10.

Key words and phrases: set-valued mapping, generalized vector quasi-variational-like inequalities, $L-\eta$-condition, existence.

\section{REFERENCES}

[1] F. GIANNESSI, Theorems alternative, Quadratic programs, and complementarity problems, In variational inequalities and complementarity problems, (Edited by R. W. Cottle, F. Giannessi, and J. L. Lions), pp.151-186, John Wiley and Sins, New york, 1980.

[2] G. Y. CHEN, G. M. CHENG, Vector variational inequalities and vector optimization, In Lecture Notes in Economics and Mathematical Systems, 285, (1987), 408-456.

[3] G. Y. CHEN, Existence of solutions for a vector variational inequality: an existension of the HartmannStampacchia theorem, J. Optim. Theory and Appl., 74, (3) (1992), 445-456.

[4] G. Y. CHEN, X. Q. YANG, Vector complementarity problems and its equivalences with the weak minimal element in ordered spaces, J. Math. Anal. Appl., 53, (1990), 136-158.

[5] G. Y. ChEN, B. D. CRAVEN, Approximate dual and approximate vetor variational inequality for multiobjective optimization, J.Austral. Math. soc., Ser. A 47, (1989), 418-423.

[6] G. Y. CHEN, B. D. CRAVEN, A vector variational inequality and optimization over an efficient set, Zeitschrift fur operations Research, 3, (1990), 1-12.

[7] A. H. SidDIQI, A. H. ANSARI, Khaliq A, On vector variational inequality, J. Optim. Theory Appl., 84, (1995), 171-180.

[8] X. Q. YANG, Vector complementarity and minimal element problems, J. Optim, Theory Appl. 77, (1993), 483-495.

[9] X. Q. YANG, Vector variational inequality and duality, Nonlinear Analysis, Theory, Methods \& Applications, 21, (11) (1993), 869-877.

[10] X. Q. YANG, Generalized convex functions and vector variational inequality, J. Optim. Theory Appl., 79, (1993), 563-580.

[11] S. J. YU, J. C. YAO, On vector variational inequality, J. Optim. Theory Appl., 89, (1996), 749-769.

[12] G. M. LEE, D. S. KIM AND S. J. CHO, Generalized vector variational inequality and fuzzy extension, Appl. Math. Lett., 6, (6) (1993), 47-51.

[13] G. M. LEE, D. S. KIM AND B. S. LEE, Generalized vector variational inequality, Appl. Math. Lett., 9, (1) (1996), 39-42.

[14] K. L. LIN, D. P. DING AND J. C. YAO, Generalized vector variational inequalities, J. Optim. Theory and Appl., 92, (1) (1997), 117-125.

[15] I. V. KonNOV, J. C. YAO, On the generalized vector variational inequality problem, J. Math. anal. Appl., 206, (1997), 42-58.

[16] A. DANIILIDI, N. HADJISAVvas, Existence theorems for vector variational inequalities, Bull. Austral. Math. Soc., 54, (1996), 473-481.

[17] X. Q. YANG, J. C. YAO, Gap functions and existence of solutions to set-valued vector variational inequalies, J. Optim. Theory and Appl., 115, (2) (2002), 407-417. 
[18] W. Oettli, D. Schlager, Existence of equilibria for monotone multivalued mappings, Math. Meth. Oper. Res., 48, (1998), 219-228.

[19] G. Y. CHEN, S. J. LI, Existence of solutions for a generalized vector variational inequality, J. Optim. Theory Appl. 90, (1996), 321-334.

[20] G. M. LeE, B. S. LeE AND S. S. ChANG, On vector quasivariational inequalities, J. Math . Anal. Appl., 203, (1996), 626-639.

[21] Q. H. ANSARI, A note on generalized vector variational-like inequalities, Optimization, 41, (1997), 197-205.

[22] Q. H. ANSARI, Extended generalized vector variational-like inequalities for nonmonotone multivalued maps, Ann. Sci. Math., 21, (1) (1997), 1-11.

[23] X. P. DING, E. TARAFDAR, Generalized vector variational-like inequalities without monotonicity, pp. 113-123. Vector variational inequalities and vector equilibrium: mathematical theoreies, In: Giannessi, F. (Eds.), Kluwer Academic Publishers, 2000.

[24] X.P. DING, E. TARAFDAR, Generalized vector variational-like inequalities with $C_{x}-\eta$-pseudomonotone set-valued mappings, pp. 125-140. Vector variational inequalities and vector equilibrium: mathematical theoreies, In: Giannessi, F. (Eds.), Kluwer Academic Publishers, 2000.

[25] Q. LuO, Generalized vector variational-like inequalities, pp. 363-369. Vector variational inequalities and vector equilibrium: mathematical theoreies, In: Giannessi, F. (Eds.), Kluwer Academic Publishers, 2000.

[26] X. P. DING, The generalized vector quasi-variational-like inequalities, Computers and Mathematics with Applications, 37, (1999), 57-67.

[27] H. H. SCHAEFER, Topological vector space, Springer-Verlag, Newyork, 1971.

[28] A. Q. SIDDIQI, Q. H. ANSARI AND Q. A. KHALI, On vector variational inequality, J. Optim. Theory and Appl., 84, (1995), 171-180.

[29] M. H. SHIH, K. K. TAN, Generalized quasi-variational inequalities in locally convex topological vector spaces, J. math. Anal. Appl., 108, (1985), 333-343.

[30] J. X. ZHou, G. CHEN, Diagonal convexity conditions for problems in convex analysis and quasivariational inequalities, J. Math. Anal. Appl., 132, (1988), 213-225.

[31] D. CHAn, J. S. PANG, The generalized quasi-variational inequality problem, Math. of Oper .Res., 7, (1982), 211-222.

[32] X. P. DING, K. K. TAN, Generalized variational inequalities and generalized quasi-variational inequalities, J.Math . Anal. Appl., 148, (1990), 497-508.

[33] X. P. DING, Existence of solutions for generalized quasi-variational-like inequalities, Appl. Math. Mech., 18, (1997), 141-150.

[34] X. P. DING, Generalized variational-like inequalities with nonmonotone set-valued mappings, J. Optim. Theory Appl., 95, (1997), 601-613.

[35] X. Z. YUAN, E. TARAFDAR, Generalized quasivariational inequalities and some applications, Nonlinear Anal. TMA, 29, (1997), 27-40.

[36] J. P. AUBIN, I. EKELAND, Applied nonlinear analysis, Wiley-Interscience, New York, 1984.

[37] G. Q. TIAN, J. X. ZHOU, Quasi-variational inequalities without the concavity assumption, J. Math. Anal. Appl., 132, (1993), 289-299.

[38] C. H,. Su, V. M. Sehgal, Some fixed point theorems for condensing multifunctions in locally convex spaces, Proceedings of the National Academy of Sciences of the U.S.A., 50, (1975), 150-154.

[39] E. MichaEL, A note on paracompact spaces, Proceedings of the American Mathematical Society, 4, (1953), 831-838.

[40] K. FAN, Fixed-point and minimax theorems in locally convex topological linear spaces, Proceedings of the National Academy of Sciences of the U.S.A., 38, 1952, 121-126. 